Témoigner Témoigner. Entre histoire et mémoire

Getuigen Revue pluridisciplinaire de la Fondation Auschwitz

$122 \mid 2016$

Révisionisme et négationisme

\title{
Patrice Perna et Fabien Bedouel, Kersten, médecin d'Himmeler
}

Jean-Pierre Pisetta

Traducteur : Gorik de Henau

(2) OpenEdition

Journals

Édition électronique

URL : https://journals.openedition.org/temoigner/4845

DOI : $10.4000 /$ temoigner.4845

ISSN : 2506-6390

Éditeur :

Éditions du Centre d'études et de documentation Mémoire d'Auschwitz, Éditions Kimé

Édition imprimée

Date de publication : 2 mai 2016

Pagination : 163-164

ISSN : 2031-4183

Référence électronique

Jean-Pierre Pisetta, «Patrice Perna et Fabien Bedouel, Kersten, médecin d'Himmeler», Témoigner. Entre histoire et mémoire [Online], 122 | 2016, Online op 30 septembre 2021, geraadpleegd op 03 janvier 2022. URL: http://journals.openedition.org/temoigner/4845 ; DOI: https://doi.org/10.4000/temoigner. 4845

Ce document a été généré automatiquement le 3 janvier 2022.

Tous droits réservés 


\title{
Patrice Perna et Fabien Bedouel, Kersten, médecin d'Himmeler
}

\author{
Jean-Pierre Pisetta \\ Traduction : Gorik de Henau
}

\section{RÉFÉRENCE}

Patrice Perna (scenario), Fabien Bedouel (tekeningen), “Pacte avec le mal”, Kersten, médecin d'Himmeler - 1, Grenoble, Glénat, 2015, 48 p.

Patrice Perna (scenario), Fabien Bedouel (tekeningen), “Au nom de l'humanité”, Kersten, médecin d'Himmeler - 2, Grenoble, Glénat, 2015, 48 p.

1 Reichsführer Heinrich Himmler heeft verschrikkelijke maagpijn waar geen enkele Duitse arts aan kan verhelpen. Tot hij in 1939, voor de oorlog uitbreekt, een beroep doet op Felix Kersten, een Finse kinesitherapeut die er via handoplegging en diverse massages in slaagt de pijn op wonderbaarlijke wijze te verlichten. Dankzij die zorgen komt hij in de gunst en krijgt hij het gedaan dat politieke tegenstanders van het naziregime in Duitsland en Nederland (waar Kersten een huis en talrijke vrienden heeft) worden vrijgelaten.

In 1941 verneemt de verzorger dat Hitler, geïrriteerd door de nauwe banden tussen het Nederlandse hof en Joodse middens, heeft besloten om de Nederlandse bevolking massaal naar Polen te deporteren. Kersten zou hebben verkregen dat Himmler bij Hitler tussenbeide kwam om van dit project af te zien, hoe onwaarschijnlijk dit ook moge klinken.

3 Het verhaal van scenarist Patrice Perna en tekenaar Fabien Bedouel verloopt via twee hoofdlijnen. De eerste heeft betrekking op de oorlogsperiode, de tweede op de naturalisatieaanvraag die Kersten na het einde van de vijandelijkheden indient bij de Zweedse autoriteiten (waarom precies bij hen licht de auteur niet toe). Vanwege Kerstens banden met het naziregime verwerpt de administratie in Stockholm zijn dossier, waarin hij nochtans als een held wordt omschreven. Maar dat hij levens redde, 
was net het resultaat van die banden. Zo wist hij te bereiken dat heel wat Scandinavische gevangenen uit de kampen werden vrijgelaten en naar Zweden gebracht. Het land had zich bereid verklaard hen op te nemen na bemiddeling door het Zweedse Rode Kruis, dat toen onder leiding stond van graaf Folke Bernadotte. Die laatste kon jammer genoeg geen goed woordje meer voor hem doen, want hij was in 1948 door extremisten in Palestina vermoord. Tegelijk hadden Bernadotte en Kersten verkregen dat een transport van duizenden Joden naar Zwitserland werd omgeleid, wat ook door Himmler was goedgekeurd, nog altijd uit erkentelijkheid voor Kerstens toegewijde zorgen.

4 Via deze twee albums, getekend met een verfijnde en treffende soberheid, wordt het grote publiek ingelicht over verbazingwekkende gebeurtenissen en krijgt het een cruciale vraag voorgeschoteld: als je een pact hebt gesloten met 'het kwaad' of met 'de duivel' - de eerste term staat op het omslag, de tweede vreemd genoeg op het titelblad! - kun je dan werkelijk aanspraak maken op verzachtende omstandigheden door ondanks alles levens te redden? Want als je een dergelijk individu verzorgt, dan stel je hem toch ook in staat om zijn taak als rechterhand van Hitler tot een goed einde te brengen, en bijgevolg diens vernietigingswerk? Een lastige vraag waar de albums maar op antwoorden door de feiten mee te delen, dus zonder de knoop door te hakken. De lezer moet zich zelf maar een mening vormen, op knap lastige wijze.

5 Was het in dit afgewogen en nauwkeurige werk trouwens nodig om een volledige bladzijde te wijden aan de bedgeheimen van een ondergeschikte nazi en de welvingen van diens minnares? Het arme kind wordt niet alleen in evakostuum aan onze blikken blootgesteld, maar krijgt ook nog een standje omdat ze het aandurft de nazigroet te brengen terwijl haar minnaar alweer is aangekleed. Die vrouw dient hier duidelijk als (blote) excuustruus. 